THE ITALIAN SERVIZIO SANITARIO NAZIONALE: A RENEWING TALE OF LOST PROMISES

GILBERTO TURATI

Working paper No. 21 - July 2011 


\title{
The Italian Servizio Sanitario Nazionale: a renewing tale of lost promises
}

\author{
Gilberto Turati \\ Department of Economics and Public Finance "G. Prato" \\ University of Torino
}

June 2011

This paper has been prepared as the chapter on the Italian health care system for the book by $\mathrm{J}$. Costa Font and S. C. Greer (eds.), Federalism and decentralization in European Health and Social Care: Competition, Innovation and Cohesion, to be published in 2012 by Palgrave. I am indebted with Massimo Bordignon, Nerina Dirindin, Massimiliano Piacenza, and Franco Reviglio for the ongoing discussions on the issues discussed in this work. Needless to say, I am the sole responsible for all the errors and the opinions expressed here. 


\section{Introduction}

According to the Italian Constitution, article 32, "the Republic protects health as a fundamental individual right and in the public interest. It guarantees free of charge health care services to the poor". It is in the light of this Constitutional provision, with a strong flavour in terms of equity, that one needs to begin the journey through the evolution of the Italian health care system, from its creation at the end of the Seventies up to now. To present the road ahead, I will first concentrate on presenting the evolution of the system in Section 1. I will then discuss the results of about thirty years of the Italian Servizio Sanitario Nazionale - both in terms of efficiency and equity - in Section 2. I leave to Section 3 some thoughts on the future problems to be solved, including the current policy discussion and the long-run impact of population ageing.

\section{A brief (institutional) history of the Italian Servizio Sanitario Nazionale}

\subsection{From the creation of the SSN to European constraints on public finances}

Three are the fundamental reforms that structured the Italian Servizio Sanitario Nazionale (SSN from now on): the Law 833/1978; the Legislative Decrees 502/1992 and 517/1993; the Legislative Decree 229/1999. The first of these laws basically created the SSN, by substituting over 100 health insurance funds - largely a reflection of the corporative nature of the Italian Welfare State - with a unique universal and comprehensive public fund. The second and the third reforms were instead implemented during the Nineties, an era of extensive reforms and counterreforms pushed forward in an effort of reaching a new equilibrium for the Italian public finances, plagued by a huge stock of debt. 


\subsubsection{The creation of a National Health Service}

The Law 23 December 1978 n. 833 - mainly due to the Christian Democrat Tina Anselmi, the Health Minister in the Government guided by Giulio Andreotti - gave substance, after thirty years, to Art. 32 of the Italian 1948 Constitution, by stating that "the Republic protects health as a fundamental individual right and in the public interest by means of the Servizio Sanitario Nazionale (National Health Service)" (art. 1). The National Health Service is defined by the same law as "the complex of functions, structures, services, and activities directed to the promotion, maintenance, and recovery of physical and mental health of the whole population, without any differences of individual and social conditions, assuring equalities of all citizens with respect to the Service". Not surprisingly, given the fragmentation and the inequalities created by the previous system of health insurance funds, the goals established in the law are markedly related to extending the coverage to a comprehensive set of services and to improve equity in health ${ }^{1}$. Section III of Law 833/78 contains a detailed description of all services to be provided by the SSN: preventive care, services to guarantee health and safety at work, GPs and specialist care services, hospital care, access to medicines.

Provision has to be guaranteed by a multi-layered organisation involving the Central Government, the Regional Governments and a number of Local Health Units. Central Government is in charge only of defining, together with Regional Governments the goals to be pursued by the NHS and the levels of health care services to be guaranteed all over the country. The main characters in the organisation designed by the 1978 law are surely the Unità Sanitarie Locali (USL, literally Local Health Units), newly created public bodies to pursue the goals of the

\footnotetext{
1 For instance, art. 2 states - among other issues - that the NHS aims at overtaking territorial imbalances in the social and health conditions of the country; art. 4 assigns Central Government the task to guarantee uniform conditions in some of the determinants of citizens' health (e.g., pollution, safety at work, food safety).
} 
SSN. These are complex organisations combining administrative and care services, including producers like public hospitals, and involving one or more municipalities, that can freely contract also with private producers for the provision of care.

The idea of involving municipalities in the management of health care was basically to guarantee participation of citizens to the process of planning. While probably correct in principle, this involvement resulted in a strong political control at a local level of a politically hot issue like health care. This - in turn - contributed to create large inefficiencies and a large growth in expenditure, with massive deficits generated every year (see Figure $1 \mathrm{a}$ and $1 \mathrm{~b}$ below).

Planning at the central level was to be based on the National Health Plan, ideally a three-years program defining: the amount of financing of the National Health Fund, the criteria for apportioning the Fund to Regions, the goals to be pursued by the SSN. Starting from the National Plan, Regional Governments had to define their own Regional Health Plans, sharing common goals but with freedom of choice as for the organization of services (e.g., the hospital network, the role of private providers, $\ldots)$.

The total amount of funding was (and still is) defined by the Central Government in accordance - at least in principle - with Regional Governments, distinguishing between funds for current expenditures and for investments. Allocation of funds to each Region was a task assigned to the Comitato Interministeriale per la Programmazione Economica (CIPE, literally a Inter-ministerial Committee for Economic Planning) on the basis of indices and standards to be chosen in order to guarantee territorial equity in the provision of services (art. 51, law 833/78). In turn, Regional Governments need to allocate funds to their Local Health Units in accordance with municipalities. Again, the parameters for the apportionment 
formula have to be chosen so as to assure uniform services in each Local Health Unit.

The National Health Fund was financed (up to 1992) by two basic sources: sickness contributions (to be levied on the gross wages or pensions, adding to social security contributions) and Central Government funds. Sickness contributions were guaranteed by making mandatory the enrolment to the public health insurance for all citizens starting from January $1^{\text {st }}, 1980$. Certainly, for a universal public health insurance scheme with a strong equity flavour, like the newly created SSN, these different sources of funds generated some confusion, resulting in a mix between a 'corporative' and a 'social-democratic' welfare model.

This was not, however, the main problem plaguing the SSN. Most important issues were the inabilities to plan and define goals by the Central Government, as well as the allocation of responsibilities across different layers of governments, resulting in a misalignment between expenditure and funding. As for the planning at the national level, even though the art. 54 of law 833/78 established that the first plan for the 1980-1982 period was to be presented in Parliament within April 30 th 1979 , the first National Health Plan has been really presented in 1994, after sixteen years and a new reform of the SSN. As for the spread of responsibilities across different layers of governments, this surely contributed (and still continues to contribute, at least to some extent) to create inefficiencies, corruption and waste of resources, because of: the opportunistic behaviour of local governments in the presence of the Central Government footing their bill; and a strict political control of USL, which guaranteed local politicians a large power and - consequently - a number of votes, but left citizens with worse-than-expected services given expenditure, especially in some areas of the country. The reforms put forward during the Nineties tried to tackle exactly these shortcomings of the original design of the SSN. I examine each in turn. 


\subsubsection{The 1992-1993 wave of reforms}

Public health care expenditure was out of control during the Eighties, with doubledigit annual growth rates, and ex-ante funding always inferior to ex-post expenditure (Figure la and 1b). Despite taking contrary stands, during the whole period the Central Government stepped in and bailed out regional deficits on a almost regular basis of two-three years, probably recognising some degree of underfunding (which was motivated by the short lives of governments). But the political landscape was on the eve of a critical change for the Italian public finance. In 1992, after a severe political and financial crisis, that basically destroyed the old system of political parties and brought the country close to default, the Central Government defined one of the most impressive fiscal crunch of the Italian history, making the first painful steps on the way to meet the Maastricht Treaty constraints. The ratification of the Treaty is a landmark in the management of post-war public finance in Italy: it made clear that the huge deficits of the past were unsustainable, and opened the door to a number of reforms aiming at controlling expenditure in a 'structural' way. These winds of change touched, among other issues, electoral rules (to strengthen governments in power at all levels), pensions, and - of course - health care.

The 1992-1993 reforms due to a Centre-Left governing coalition guided by Giuliano Amato tried to address all the problems afflicting the SSN. As for the inefficiencies in the provision of services, and the political control of USL, the reforms were inspired by the introduction of quasi-markets in the British NHS in 1990. Basically, the idea behind quasi-markets was to split providers from purchaser of services, in order to obtain - via competition for patients - a boost in efficiency, without any changes in the equity to be guaranteed in a universal public health insurance scheme. This was exactly the objective pursued by Central Government. However, well-known potential drawbacks in the quasi-markets organisation are the increase 
in the volume of services, the lack of competition in some areas of the country, and the cream-skimming of patients by certain types of providers. Of course, given these drawbacks, at this stage there was no empirical evidence on the effectiveness of this mechanism in curbing expenditure, which was a second main goal to be pursued with the reforms.

Figure 1a. Current expenditure and funding in the NHS (1987-2009, mln euro)

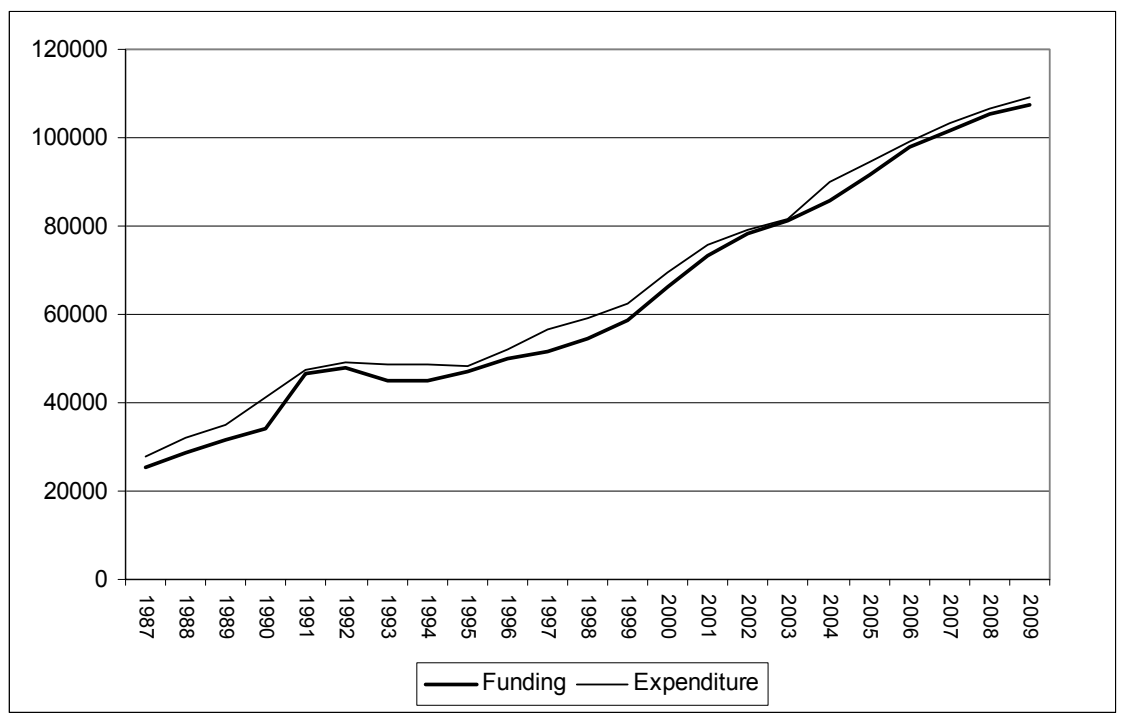

Figure 1b. Current expenditure and funding year-to-year annual growth rates (1987-2009, \%)

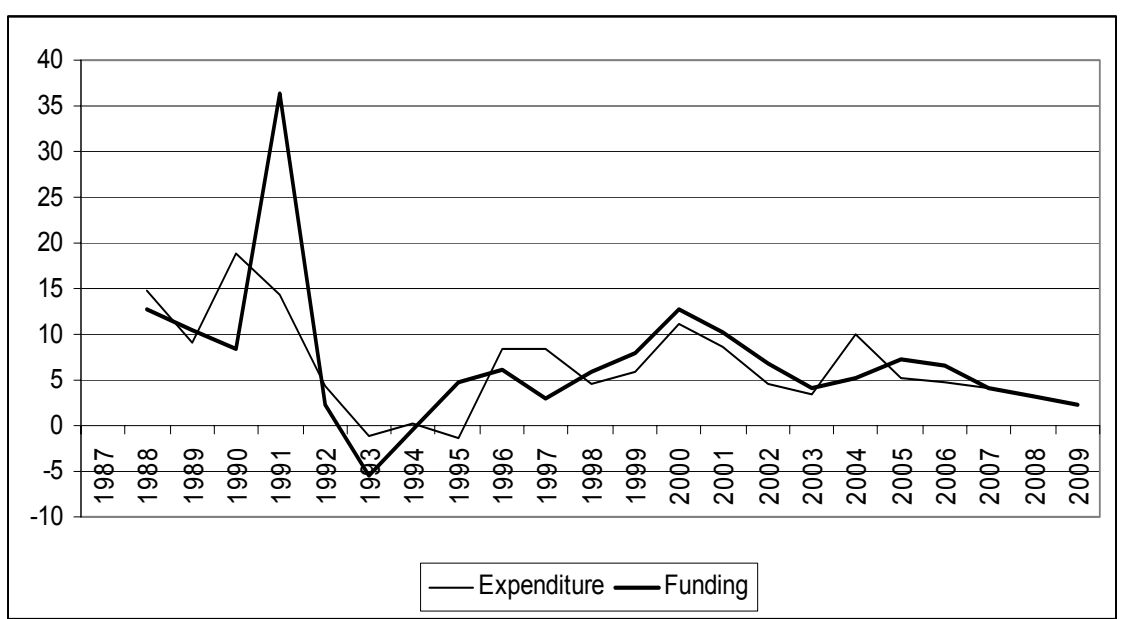

Source: Relazione Generale sulla Situazione Economica del Paese 
The move toward quasi-markets required several different changes. First, USL were transformed into Aziende Sanitarie Locali (ASL, literally Local Health Firms), independent public bodies with their own organisation, budget, and management. In essence, the law designed a new type of publicly owned firm, with a strong focus - at least in the aim of its proponents - on the efficient management of the budget. This is why the 1992-1993 reforms are often identified in Italy as the 'businesstransformation' of the SSN. The transformation in ASL had at least two important implications: first, any links with municipalities were cut, with the balance of power now in favour of Regional Governments; and this would have helped in eliminating political control by local politicians. Second, it required a new internal organisation, quite close to that of a private firm: a Board of Directors and a Chief Executive Officer, to be appointed by Regional Governments; a Board of Statutory Auditors for internal audits, with up to five members appointed by Regional Governments (2 members), the Municipal Governments (1), and the Ministry of the Economy (2). As we will see below, however, the political control - once finding close the door of Municipal governments - came back through the window of Regional governments. Moreover, despite the design of an efficient internal organisation, ASL were (and still are in some cases) far away from managing funds efficiently: managers appointed by politicians sometimes rely more on political pressures than on market forces in allocating funds; the internal auditors sometimes do not audit much.

A second change required by the move toward the quasi-market model was to separate producers from purchasers of services. The basic implication here was for ASL to hive off hospitals, and create the so-called Aziende Ospedaliere (AO, literally Hospital Firms). ASL were supposed to retain mostly administrative services (including the definition of needs at the local level), and then contract with different producers (from GPs to newborn AO) services for their policyholders (i.e., all residents in their jurisdiction). Again, this fundamental change had different implications: since the ASL had to contract with producers, they also needed to 
define a price for the services to be purchased. The solution proposed was to introduce a prospective payment system (PPS) based on Diagnosis Related Groups (DRG) - created in the US at the beginning of the Eighties and experimented in the US Medicare - which basically substituted per-day fees for private providers and full ex-post payment for public hospitals ${ }^{2}$. In turn, this solution implied a change in hospital management, imposing an administrative burden on nurses and physicians: the Scheda di Dimissione Ospedaliera (SDO, literally Discharge Form) had to be filled in order to require payment from the ASL of the hospital services provided. Of course, the SDO was useful to identify for each patient the DRG and the corresponding tariff; but the tariffs had still to be defined. After the initial proposal of a national listing of charges, Regional Governments were set free to adopt their own. In any case, the new PPS had to be started between 1995 and 1997; in the absence of regional tariffs, Regions should then adopt the national ones. Again, also these changes were more promised than realised: only one region (Lombardy) separated all providers from purchasers. Moreover, after the initial years following the reform, also the PPS-DRG system was partly abandoned in favour of a budgetbased approach, especially with private producers.

As for the SSN funding, the 1992-1993 reforms emphasised the change in the balance of power in favour of Regional Governments, by explicitly assigning sickness contributions to regional budgets. Together with the introduction of a property tax to finance municipalities in the same year, this was the first fundamental move towards the introduction of some degree of fiscal decentralization in the Italian context. The move has to be interpreted as a first trial to explicitly solve the misalignment between expenditure and funding responsibilities, in order to make more accountable local governments. It was inspired both by the pressures exercised by new political parties combating against corruption and inefficiencies, that rapidly

\footnotetext{
2 Of course, also the DRG-PPS system has its pros in the fact that - being a fixed price mechanism it should boost efficiency. But it also have its own cons, like up-coding, cream-skimming, skimping, dumping, ...
} 
gained votes in Northern Regions (especially the Lega Nord, literally North Alliance), and by the precepts of second-generation fiscal federalism theories, rapidly evolving those same years (e.g., Oates, 2005; Weingast, 2009). To emphasise that the devolution of own resources to Regional Governments was aimed at increasing their accountability, the Legislative Decree 502/92 explicitly excluded that the Central Government would take care of any future deficits (art. 13). Unfortunately, this is another unfulfilled promise.

Given the introduction of a seminal form of fiscal federalism, the apportionment of the National Health Fund slightly changed. The major change was not in the apportionment formula itself (still based on some parameters identifying needs), but in the logic behind the working of the Fund. After devolution of sickness contributions, the role of general taxation was to top-up regional resources in order to cover regional financial requirements. The huge territorial differences in the tax bases caused (and still cause) very different vertical imbalances for each region: in particular, Southern regions need to receive more funds from Central Government than Centre-Northern regions. The equalisation role played by the National Health Fund was then magnified in this new context. This presumably propelled the tensions among regions, and further strengthened the idea to move toward a more mature form of fiscal federalism.

\subsubsection{The 1999 reform}

The call for fiscal federalism received another boost after the substitution of sickness contributions with both a newly created regional tax, the Imposta Regionale sulle Attività Produttive (IRAP, literally Regional Tax on Productive Activities), and a Surcharge on Personal Income Tax (Addizionale IRPEF), proposed by the CentreLeft coalition guided by Romano Prodi in 1997. 
Despite this trend, however, that should have increased regional responsibilities, deficits were more the rule rather than the exception after some years of retrenchment (see Figure la above). Moreover, the quasi-market model and the role of competition in improving efficiency was contrasted by the Health Minister Rosy Bindi, who pushed more on equity as for the role assigned to the SSN, getting back with the 1999 reform to the original spirit of the 1978 law.

The Legislative Decree 229/99 introduced the notion of Livelli Essenziali di Assistenza (LEA, literally Essential Levels of Care), i.e., mandatory and uniform services to be guaranteed in all regions. At present, the only definition of LEA consists of a positive list of all services to be included in the public insurance scheme and a negative list of all services excluded, defined with the Agreement between Central and Regional Governments of August $8^{\text {th }}, 2001$. The choice of what services are included and what services are excluded is based on their effectiveness. Besides fixing this principle, however, the notion of LEA has an operational content which is difficult to grasp.

Given that some services are explicitly excluded from those provided by the SSN, the Legislative Decree 229/99 introduced also Supplementary Funds of the SSN (art. 9). These are thought as public or private insurance schemes that cannot select risks and can offer coverage for (1) all the services excluded from SSN and (2) the copayments required for some of the services included in the LEA. At present, they play a very minor role in the Italian landscape: not surprisingly, private health care spending in Italy is almost entirely out-of-pocket.

As already discussed, the Legislative Decree 229/99 also reneged the quasi-market model just introduced, and called for more 'co-operation' between ASL and providers, particularly private providers. In essence, this meant that ASL should 
contract with private providers assigning them a given budget and a given role in the provision of services.

The 1999 reform also pushed for more integration between health care and social care policies, again stressing the role of $\mathrm{SSN}$ in combating inequities, deprivation and social exclusion (art. 3 - septies). Integration involved the responsibility of municipalities in providing social services to disadvantaged people, like the elderly. Included are services like those provided by, e.g., nursing homes.

Finally, the 1999 reform made it definitely clear that the management of health care services was a responsibility of Regional Governments. In the light of these changes, it was more a reform setting principles than a reform aimed at solving the structural problems of the SSN. Despite the effectiveness implicit in the definition of the LEA, these principles were those characterising the original design of the SSN: a clear emphasis on equity, and a much less focus on efficiency.

\subsection{The dawn of the new century in the Italian SSN}

The Italian SSN stemming from reforms implemented during the Nineties appears to be different from the original design of the Law 833/78, even though - at the beginning of the new century - it was (and still is) unclear the shape of the new project. The conflict between reforms and counter-reforms that characterised the first twenty years of the SSN are most likely deriving from an apparent tension between efficiency and equity, which characterised also the first ten years of the new century.

Despite the difficulties in identifying the whole picture, there are then few important pieces of the puzzle that can help in clearing potential developments. A first 
undisputed piece of evidence is that the Regions are the layer of government in charge of managing health care. This has been sanctioned both by reforms implemented during the Nineties, and by the recent Constitutional Law n. $3,18^{\text {th }}$ October 2001. Article 117 of the newly reformed Constitution define competencies for the different levels of government. In particular, Art. 117 comma 1 letter (m) assigns to the Central Government the exclusive right to only "define the Essential Levels of Services linked to civil and social rights to be guaranteed in the whole country". Health care services are of course included, so that only the Central Government can identify the mandatory level of care to be assured in all regions, and has the exclusive right to define the framework legislation. However, Art. 117 comma 2 states that the "protection of health" is a shared responsibility between the Central Government and the Regional Governments. The common interpretation of this statement is that the management of the health care systems at the local level is responsibility of Regional Governments, that have to exercise their freedom within the framework legislation established by the Central Government.

Hence, the organisation of the SSN is essentially unchanged from the 229/99 reform. Basically every Region can choose how to organise the provision of services, and the role of the Central government is only to define the framework. This includes, for instance, the list of essential services, but also the main directions to be pursued by Regional governments. For example, assigning more resources to territorial care and reducing the role played by acute care hospitals are two trends inspired by policies at the national levels, that (should) direct Regional choices.

A second undisputed stylised fact is the difficulty in implementing a new system of funding, with the aim of making Regional governments more accountable. Clearly enough, the involvement of different layers of governments in health care makes the issue of funding the SSN intertwined with the introduction of fiscal federalism in the Italian system of governments. As the story goes, there have been many different 
attempts to implement a seminal form of fiscal decentralisation in the country, proposed by both Centre-Left and Centre-Right governing coalitions, but none have been successful so far. The Legislative Decree $n .56,18^{\text {th }}$ February 2000, is the first comprehensive law aimed at changing regional funding in Italy, by eliminating earmarked transfers and reducing vertical imbalance. It was implemented by the Centre-Left governing coalition guided by Massimo D'Alema, a representative of the former Italian Communist Party. In particular, the Legislative Decree 56/2000: a) identifies a set of rules to define the annual funding for health care and other minor spending categories at the Regional level; b) identifies a set of taxes to fund these expenditures; c) identifies a set of rules to equalise resources taking into account differences in both regional fiscal capacities and regional needs. Differently from the past, the evolution of regional spending (of which health care represents about 4/5) have been thought to be consistent with the evolution of the main taxes on which funding was based. These were the Regional Tax on Productive Activities (IRAP) and a Surcharge on Personal Income Tax (Addizionale IRPEF), introduced in 1997, plus the increase in revenues' sharing on the Specific Tax on Gasoline and - more importantly - the introduction of revenues' sharing on the Value Added Tax (IVA).

The philosophy inspiring the project was to increase regional accountability by both increasing Regions' fiscal autonomy and - contemporaneously - the freedom to manage their budget within the limits of the framework legislation defined at the Central level (removing earmarked transfers). In this perspective, the "solidarity coefficient' in the equalisation formula was fixed at $90 \%$ to guarantee an 'incomplete' equalisation. In other words, part of the own revenues were excluded from equalisation to provide appropriate incentives to Regional governments to correctly manage their revenues. Not surprisingly, this mechanism would have favoured Regions with a larger fiscal capacity (i.e., mostly Northern Regions). 
Apportionment of resources in 2001 did not provoke any reaction by the Regions, simply because this was based on past expenditures. In 2002, however, $5 \%$ of the resources were to be shared according to the new criteria (fiscal capacity and needs), while the remaining $95 \%$ on the basis of past expenditures. This was established by the Decree 56/2000 in order to allow Regional governments to adjust slowly (in 13 years) to the new rules. In fact, in 2013 all resources would have been apportioned according to the new criteria fixed by the Decree. But the new criteria were never applied: as soon as it has become clear that some Regions lost part of their funds, Regional governments blocked the Decree. In particular, Campania and Puglia two Southern regions - appealed to the Constitutional Court by exploiting the basic principle of the SSN, that views health as a 'fundamental individual right' to be protected by the Republic. Central government was then forced to 'suspend' the Decree.

The following years are characterised by a large uncertainty surrounding the allocation of funds to Regions, that end up in a new agreement signed by the Central and the Regional governments, translated into law with the Budget Law for the year 2006 (Law 266/2005, art. 1, comma 320 and following). By the 2006, however, the Decree $56 / 2000$ is substantially dead.

New proposals on how to reform funding of lower tiers of governments (including Regional governments) came up from both the Central government and one of the leading Regional governments (the Regione Lombardia), but none has been ever translated into law. One need to wait the Law 42/2009 proposed by the Centre Right governing coalition leaded by Silvio Berlusconi to discuss again on how to introduce fiscal federalism in the Italian system of government. The principle fixed by this new law is that of 'standard costs'; but nobody knows exactly what the law means 'standard costs' exactly are. The recent Legislative Decree 68/2011 (aimed at translating the Law 42/2009 into practice) defines the criteria to compute "standard 
costs', and - in particular - the Regional Health Services to be used as benchmarks. However, how the 'standard costs' will influence the allocation of funds is still unclear. The apportionment of funds is still based on a measure of needs as in the past, while the total amount of resources is defined according to macroeconomic constraints on public budget. The agreement for 2010 confirms this view, postponing to the future the complete implementation of the new mechanism (e.g., Muraro, 2011).

\section{An overall evaluation of the Italian SSN: where do we stand?}

In this Section of the essay, I discuss the impact of these regulations on efficiency and equity in the provision of health care services in Italy ${ }^{3}$ I start by considering the country as a whole, comparing the performance of the Italian SSN with the performance of health care systems in other similar European countries. I then move to the analysis of regional differences.

Taken together, the Italian SSN performs fairly well with respect to other spending categories (for instance, education). Following a pattern similar to most Western countries, health care expenditure reached $7.1 \%$ of GDP in 2009 , with an increase in the last year mainly due to the fall in the denominator than to an increase in spending (Figure 2). However, compared to other countries, like France, Germany and Sweden, the level of spending is lower: Italians spend less during the whole first decade of the XXI century; only Spain spent a bit less during the same period. Also the recent dynamics is relatively slow: differently from the past, when - especially at the end of the Eighties - the rate of growth was worrisome, being well above $10 \%$ each year, the rate of growth is recently under control and further slowing down (see

\footnotetext{
3 This Section draws on a speech (joint with Massimo Bordignon) before the Scientific Committee of Confindustria, the Italian organisation of manufacturing and services companies, in July 2010.
} 
Figure $1 \mathrm{~b}$ above). According to Joumard et al. (2010), in real terms the average rate of growth of per capita health care spending in Italy was $2.5 \%$ in the period 1995 2007, while the average for the OECD countries was $4.1 \%$.

Figure 2. Health care spending in percentage of GDP (1987-2009)

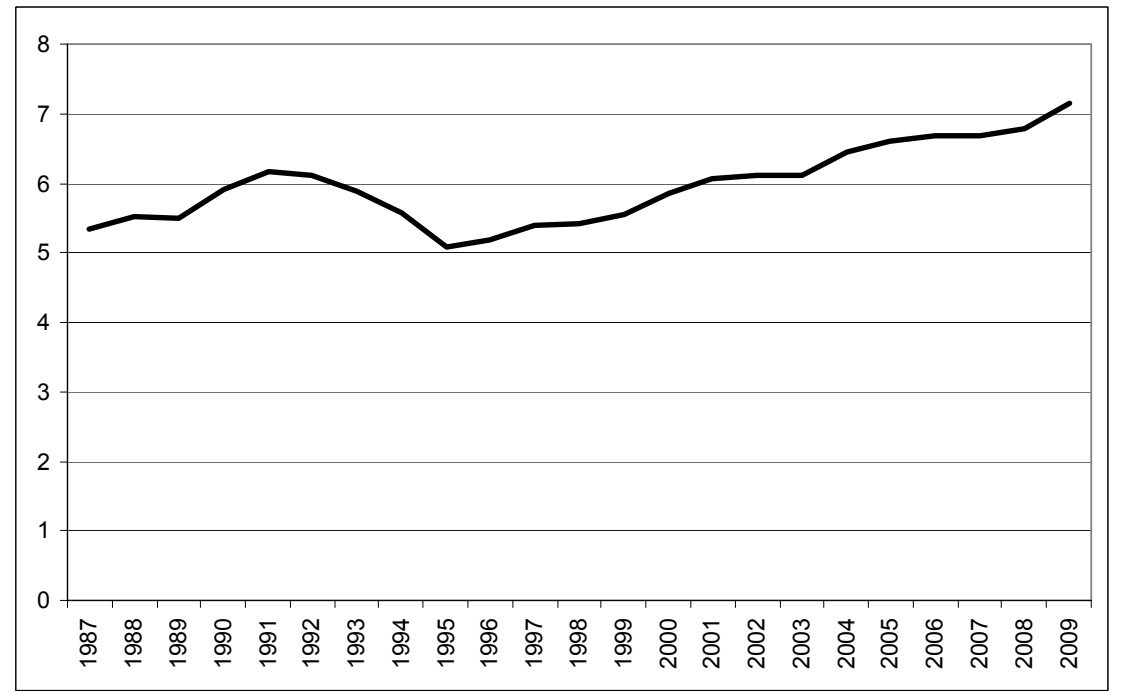

Source: Relazione Generale sulla Situazione Economica del Paese

Despite spending less, results obtained in terms of population health are even better than other countries. Considering again Joumard et al. (2010), if we look at average life expectancy at birth as an indicator of population health, Italy obtained a gain of 3.1 years over the period 1995-2007, which is the average gain obtained in the OECD countries. Similar conclusions are obtained by looking at average life expectancies at different ages, but also at infant mortality rate, which dropped massively from 81 to 37 per 10.000 births during the Nineties. The same figure dropped from 68 to 47 per 10.000 births in the EU 16 countries over the same period. Given these figures, it does not come as a surprise that the benchmarking exercise conducted by Joumard et al. (2010) suggests Italy is doing quite well in the group of 'heavily regulated public systems and with a stringent budget constraint', which includes countries like UK. 
If we consider more complete evaluation exercises, these conclusions do not change very much. For instance, in one of the benchmarking exercises carried out across countries, the World Health Organization ranked health care systems according to three goals that they should pursue: the level and the distribution of health, the level and the distribution of responsiveness, the fairness in financial contribution (WHO, 2000). Ranking $11^{\text {th }}$ in terms of per-capita total health spending, the Italian SSN ranked $2^{\text {nd }}$ taking into account all the three goals, just behind the French system, which is however the $4^{\text {th }}$ in terms of spending. Germany, ranking $3^{\text {rd }}$ for spending, performs poorly compared to Italy, since it is only $25^{\text {th }}$ in terms of overall evaluation.

But this fairly nice picture at the country level hides unacceptable differences at the regional level, and generalised problems in terms of governance and control of regional health care systems. Average per-capita spending totalled about 1,800 euro in 2009 (Ministero dell'Economia e delle Finanze, 2010), with a maximum of 2,170 euro in the Autonomous Province of Bolzano and a minimum of 1,671 in Sicilia, another Special Statute Region. If we restrict the attention to Ordinary Statute Regions, Molise spent 2,080 euro (the maximum) while Calabria 1,732 euro (the minimum), a sum which is quite close to per-capita spending in Lombardia $(1,763$ euro). Given large differences in terms of fiscal capacity, it is clear that the SSN operated ex-ante a strong redistribution in favour of less endowed regions (i.e., the Southern Regions). This is clear when looking at the share of own resources out of the total funding for health care, which is about half for Centre-North regions and less than $20 \%$ for Southern regions (Table 1 ).

However, this ex-ante redistribution is spoiled by Regional governments when managing the funds they receive; and, unfortunately, this is especially true for Southern Regions. Considering "ex-post redistribution", i.e. redistribution evaluated by taking into account services effectively consumed by citizens, requires spending 
levels to be corrected for a number of factors, such as population age, patients mobility, and complexity of services, in order to be somewhat comparable across regions. Conducting a similar exercise, researchers at the Bank of Italy suggests that - being 100 the per-capita spending at the national level - Southern Regions spend 104, Centre Regions 101.9, while Northern Regions only 96 (Alampi et al., 2010). In other words, Northern Regions contribute heavily to transfer resources to Southern Regions, and spend better and more efficiently the resources they retain. Evidence on this point are widespread, and can be grasped by looking at official data on the perceived quality of services (Figure 3), patient mobility, inappropriateness. All indicators point in the same direction: Southern regions are the worst performers at the country level (Piacenza and Turati, 2010; Francese and Romanelli, 2010; Francese et al., 2010).

Table 1. The structure of health care funding (Ordinary Statute Regions only, 2009, \%)

\begin{tabular}{|c|c|c|c|c|c|c|c|}
\hline & \multicolumn{3}{|c|}{ Own resources } & \multicolumn{3}{|c|}{ Transfers from Central government } & \\
\hline & $\begin{array}{c}\text { IRAP - } \\
\text { IRPEF } \\
\text { surcharge }\end{array}$ & $\begin{array}{l}\text { ASL own } \\
\text { revenues }\end{array}$ & $\begin{array}{c}\text { Extraordinary } \\
\text { revenues }\end{array}$ & $\begin{array}{c}\text { Ex-D.Lgs- } \\
56 / 00 \\
\end{array}$ & $\begin{array}{c}\text { Additional } \\
\text { transfers }\end{array}$ & $\begin{array}{c}\text { Earmarked } \\
\text { transfers } \\
\text { (ex National } \\
\text { Health } \\
\text { Fund) }\end{array}$ & Total \\
\hline North & 47.8 & 4.6 & 0.5 & 43.2 & 2.0 & 1.8 & 100 \\
\hline Centre & 44.5 & 4.3 & 0.8 & 47.7 & 0.9 & 1.9 & 100 \\
\hline South & 15.3 & 2.2 & 0.5 & 79.4 & 0.8 & 1.9 & 100 \\
\hline Italy & 38.4 & 3.9 & 0.5 & 53.9 & 1.4 & 1.9 & 100 \\
\hline
\end{tabular}

Source: Ministero dell'Economia e delle Finanze (2010)

One important question is why Southern Regions spend more. According to Alampi et al. (2010), for a number of reasons: a) because pharmaceutical and hospital expenditures is higher than in other regions, and these categories are those more costly; b) because the hospital network is badly managed: there are too many hospitals, small-sized, where people obtain inappropriate services of low quality; c) because there are too many prescriptions by GPs of inappropriate drugs, and of more costly drugs by given active ingredient. Of course, this does not solve the problem, 
and one may still ask why pharmaceutical and hospital expenditures are higher or why there are too many prescriptions by GPs in Southern Regions. There are not, however, easy answers here. One possible explanation is related to the lack of planning. For instance, Pelliccia and Trimaglio (2009) show that Regions in the Centre-North started the practice of Regional Health Plans well ahead of the first National Health Plan presented in 1994, as envisaged by the Law 833/78. On the contrary, Southern Regions started planning their Regional Health Services only at the end of the Nineties, after the Central government approved the first National Health Plan. Not surprisingly, inefficiencies are common in all areas of the country, but are highest in Southern Regions. For instance, Piacenza and Turati (2010) estimate that - between 1993 and 2006 - average inefficiencies in Southern (Ordinary Statute) regions were almost double inefficiencies in the Centre-North ones. Inefficiencies take many different forms: apart from those already mentioned above for the abnormal role assigned to hospitals, the report of the Parliamentary Commission "Carella" (from the name of its President) suggests other types. To list a few: hospitals in the South are characterised by structural deficiencies, like the absence of minimal security standard and "elementary" hygienic conditions; a greater inertia in the use of funds for healthcare facilities ${ }^{4}$; a connected problem of still unfinished or finished-but-never-used health care facilities (e.g., Caroppo and Turati, 2007).

Inefficiency however is not the sole explanation; because inefficiency sometimes is the result of corruption. Indeed, a second important explanation for the worst performance of Southern Regions is the presence in these areas of criminal organizations: public health care is - in some Regions - the first industry in terms of GDP, and this allures criminals and creates - in the absence of financial responsibility - a perverse mechanism. To clarify this point, the 'exchange' is

\footnotetext{
${ }^{4}$ This is true also for structural European funds. Again, lack of planning seems to be one of the most important reasons to explain why Regions with high needs of infrastructures are not able to spend available monies.
} 
structured as follows: criminal organizations gather vote for regional politicians, and politicians guarantee jobs and monies. Not surprisingly, then, in these realities the Regional Health Service is not thought primarily as providing services to citizens, but providing a job to some and monies to others in exchange for votes; with somebody else footing the bills (e.g., Lane, 2009).

Figure 3. People very satisfied with medical assistance in hospitals (2006)

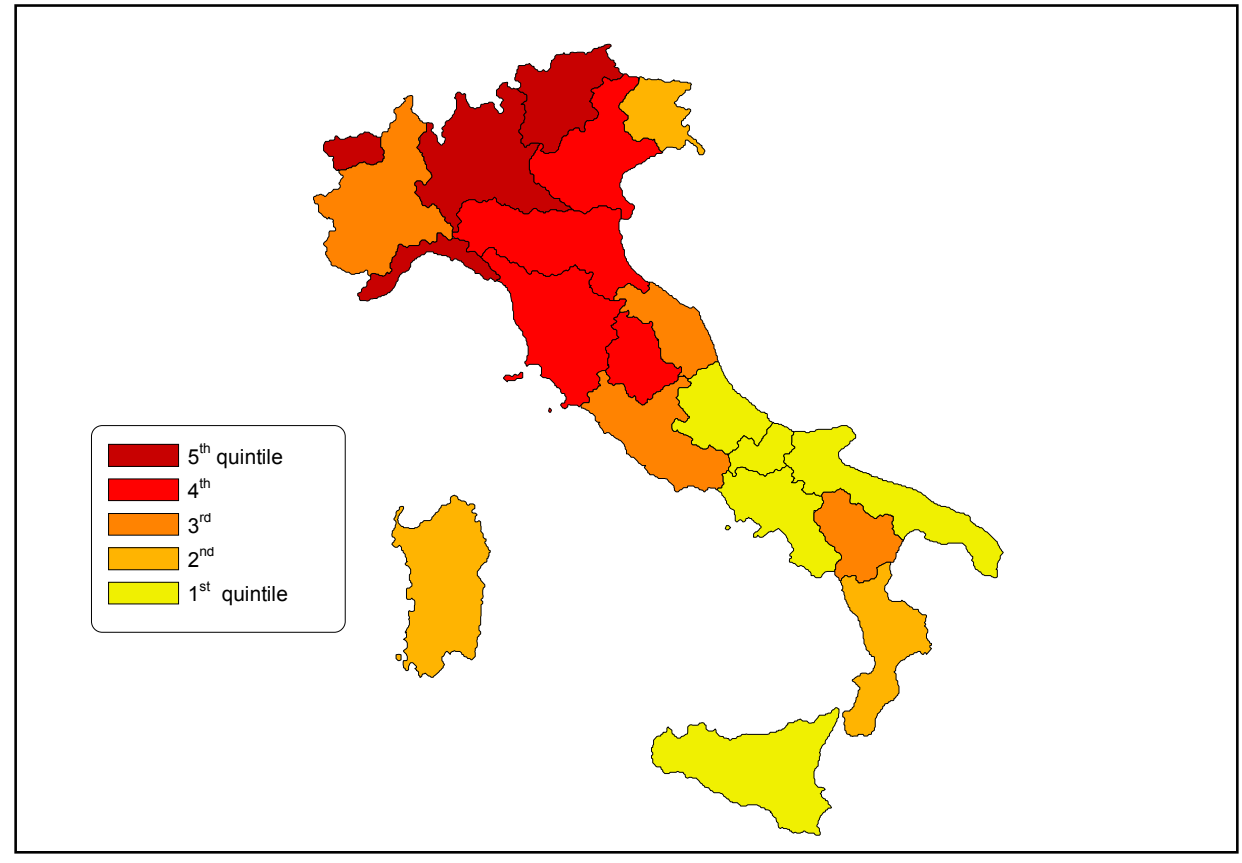

Source: ISTAT - Health for All

The presence of corruption is likely to fuel also regional deficits, that in the last few years have shown the tendency to strongly concentrate in a small subset of Southern Regions (particularly, Lazio, Campania, Puglia, Calabria, Sicilia). Notice that while the mechanism for obtaining additional funds is less "automatic" than in the past - the Central government is likely to step in and bailout past debts, should the Regional governments become unable to guarantee their financial stability (e.g., Bordignon and Turati, 2008). 
Summing up, despite the nice picture of the Italian SSN at the aggregate level, the situation at the regional level shows large differences, all pointing in a clear direction: Southern Regions perform worse than Centre-North ones. According to the available evidence, the main problem is not the lack of funds, but how (mostly) transferred funds are managed at the local level. In other words redistribution $e x$ ante (i.e., the equalisation of fiscal capacities) is not matched by ex-post redistribution (i.e., the equalisation of services for citizens). It is this mismatch that creates the tensions that will drive the likely changes in the near future.

\section{Winds of change?}

Given the good standing at the aggregate level, and the Regional differences outlined in the previous section, it is not surprising that there are tensions which are expected to characterise the future evolution of the Italian SSN. As already emphasised, in my view these tensions find their fundamental origin in the lack of correlation between ex-ante and ex-post redistribution. Centre-North Regions focus on the massive ex-ante redistribution which occurred in the past and it is still occurring today in the country, but which generated inefficiencies and corruption instead of services ex-post. According to this view, the SSN is plagued by an efficiency problem, which is related to the issue of soft budget constraints, originating from the misalignment in responsibilities of spending and funding. We have evidence that the expectations of future bailouts negatively influenced expenditure, and propelled inefficiencies (Bordignon and Turati, 2009; Piacenza and Turati, 2010). On the contrary, Southern Regions focus on the large differences in terms of availability and quality of services, which is a problem of equity in the access to health care (that can also generate a problem of equity in health). The difficulties in implementing some form of fiscal federalism clearly originate from this clash between efficiency and equity. The agreement on Regional federalism shows 
that the apportionment formula can be probably improved, but the structural problem of equalising resources in order to guarantee mandatory levels of care across the whole country cannot find an easy solution. Southern Regions will need also in the future to receive funds from other Regions; and this will continue to reduce their accountability from the financial side. ${ }^{5}$ What can we do then?

The policy discussion in the country focuses on two main interrelated types of mechanisms: on the one hand, the improvement of the "identification strategies" of inefficiencies and corruption; on the other hand, the improvement in the accountability of local politicians to be obtained by developing new and alternative political institutions (given that fiscal federalism cannot work for Southern regions). As for the first mechanism, one needs to recognise that the 1992-1993 reform package introduced a Board of Internal auditors in each ASL, with the task of auditing the budget, and reporting to Regional governments in case of irregularities and wastes in the management of public monies. Clearly enough, auditors can control the budget if there is one; but in several cases, Local Health Firms not even presented their budgets, or presented budgets that were evidently faked. One striking example of this practice is the Regione Lazio, where undisclosed past debts in 2007 amounted to 10 billion euros (Bordignon and Turati, 2008). One may ask why the Regional government did not intervene before the debt was out of control to solve the problem. One piece of the answer is probably related to the bailout received from the Central government by the Regione Lazio in the same year, which covered the surfaced debts almost completely.

If internal audits do not work, a solution could be to recur to external audits. The Italian Constitution envisages the Corte dei Conti (Court of Auditors), to which it

\footnotetext{
${ }^{5}$ Unless, of course, we reduce mandatory levels of care up to a point where all Regions can finance their services with their own funds. However, since services should be cut back heavily to allow also the poorest Region to finance its own services, this is politically unsustainable at the current stage of development of the SSN.
} 
assigns the task - among others - of controlling ex-post the management of public funds. The Court has a specific Section (Sezione delle Autonomie) dedicated to the audit of lower-tier governments' budgets. And the reports and the deliberations of the Court of Auditors are full of warnings on the management of health care funds at the regional level, especially related to Southern regions with the highest levels of $\operatorname{debt}^{6}$. Despite these recommendations, however, the Central government and the Parliament simply "shut their eyes": most reasonably, because career of politicians at the Regional level is too much intertwined with career of politicians at the Central level, for the latter being available to effectively sanction the former (Merlo et al., 2009). In a sense, Italian politicians have become a "caste" of untouchables (Stella and Rizzo, 2007).

Another mechanism to improve external audit, which suffers of this same drawback, is to improve the benchmarking of Regional Health Care services. This is the implicit aim of the original Law 42/2009, the Legislative Decree 68/2011, and the reference therein to 'standard costs'. Differently from other sectors, the availability of data is quite substantial in the case of health care. It does not come as a surprise, then, that some benchmarking exercises are already available, and others will surely follow (e.g., Piacenza and Turati, 2010; Francese and Romanelli, 2010; Pammolli et al., 2009). There is also a first report produced by the Ministry of Health on the benchmarking of Regional Health Care Systems (Ministero della Salute, 2010). But, again, once producing the evidence of inefficiencies and corruptions - substantially the same in all the benchmarking exercises - the game ends there, without any effects on the apportionment of resources. And the suspect that 'rogue' Regional governments continue managing badly public monies is still alive.

\footnotetext{
${ }^{6}$ The most recent example is the Resolution $\mathrm{n}$. 22/2009/G on the management of additional resources made available by the Central Government for the reduction of structural deficits in the SSN. The evaluation of the Court advances serious doubts on the idea that financial responsibility for Southern Regions is improving.
} 
These difficulties bring us to the second group of mechanisms, that is new institutions to improve the accountability of local politicians. A first example, already implemented but not formalised in any specific law, is the so-called Piano di Rientro (literally, a repayment plan), which is a formal agreement between the Central government and one specific Regional government that accumulated past deficits. Most of the Southern Regions already signed repayment plans, which typically include measures like the restructuring of the public hospitals network (on the expenditures side) and the (automatic) increase of the local tax rates at their maximum level (on the revenues side). But while the Minister of the Economy seems particularly happy with the experience of these plans for the future financial stability of these Regions, the Court of Auditors appears rather sceptical (see Resolution n. 22/2009/G). In any case, it would be important to translate this practice into a proper provision by the law, creating a framework legislation for the default also of Regional governments (at present, we have only bankruptcy legislation for Provinces and Municipalities), that formalises the automatic mechanism of increasing local tax rates.

A second institution that characterises the recent policy discussion is the so-called 'political failure', that is a system of disincentives for local politicians. At present, only citizens of indebted Regions (and, more generally, all Italian citizens) pay more local taxes as a 'punishment' for having elected inept representatives. However, to better control moral hazard by politicians, one should create a system of disincentives also for them. This should include the ban for local administrators who created a deficit to be commissioner of their own. At present, though incredible, the practice for Regional governments in financial difficulties is to assign additional powers to governors in office, i.e. Governors that presumably contributed to create the problem: that is, to use a 'carrot' in place of a 'stick'. A second provision should be an economic 'punishment' for local politicians, for instance by stopping remunerating the governor and all the member of the Regional Council, but also 
public funding for political parties sustaining the Regional government (Bordignon and Brusco, 2010). A third provision is the 'end-of-mandate certificate' envisaged in the recent report by the ministerial Commission for the implementation of fiscal federalism (see Relazione sul Federalismo Fiscale, June $30^{\text {th }}, 2010$, Rome). At the end of each mandate, six months before new elections will take place, the Governors should basically provide a certificate (for which they are made accountable) that the budgets they signed are representing the true and fair view of the state of affairs in their Region, so to avoid undisclosed debts.

Despite the charm of these new ideas, I find they suffer of the same problem discussed before: why (Italian) politicians should implement a set of rules that can worsen considerably their payoffs? That is why I still believe that the most important institutions are those implemented at the European level: this is the only way the Italian government can 'tie its hands' and renege any ex-post bailouts of Regional debts, so to prevent the occurrence of any financial difficulties. European rules worked apparently well in curbing bailout expectations of Regional governments in Italy during the painful adjustment to reach the goals provided by the Maastricht Treaty, wiping out deficits almost entirely (Bordignon and Turati, 2009). The provisions of the Amsterdam Treaty worked relatively less well (e.g., Piacenza and Turati, 2010): the successive crises of the Stability and Growth Pact opened the door to new problems of financial stability at the country level, which can exacerbate stability problems also at the local level, via the expectations' mechanism. I am not sure the recent European Financial Stability Facility will work. But I am sure that Europe can impose external constraints to countries with fragile political institutions, and help them maintaining financial rigidity in public finances.

Besides this "short run" standpoint, one last word on a long run perspective for the Italian SSN. In terms of spending, since expenditure is clearly age-related, rapid 
population ageing is potentially a problem for expected spending growth. A large share of inpatients and of pharmaceutical expenditure are due to people over 65 years of age, which now accounts for $20 \%$ of the total population, but are projected to grow swiftly in the next decades, more than in other countries. The picture is even worse if we consider that - for a given individual - a large bunch of the life-time health spending is concentrated in the year immediately before death. Given life expectancy at birth is now few years above 80, one can consider the share of people over 80 years out of the total population as a more precise indicator of expected growth in spending. This share, which is now about $6 \%$ for Italy, is expected to more than double by 2050 (Eurostat). Over the same period, the EU 27 average will rise from 4.6 to $11 \%$. Notice that the problem population ageing poses is not only in terms of rising expenditure, but also in terms of GDP growth: an older country will grow less, further reinforcing worries on how to finance expected increase in spending. The easy solution will be to recur to private insurance markets; and some hints in this direction have been already advanced in the policy discussion. But recurring to a 'second pillar' also for health care can be troublesome. The pensions reform implemented in 1995 will cut drastically public rents for the future pensioners, and reducing also health care services will impose a double-burden on these generations. On the one hand, they are now contributing heavily to sustain a generous welfare system for their parents, without receiving much in exchange, for instance in terms of schooling for their children. On the other hand, they will receive less in the future, because current constraints on public finances impose to restructure public welfare system to make these financially sustainable. How all this will impact on the Italian society is difficult to forecast. But, apparently, there are not good news. 


\section{Main References}

Alampi D., Iuzzolino G., Lozzi M., Schiavone A. (2010), La sanità, in Atti del Convegno "Il Mezzogiorno e la Politica Economica dell'Italia", Roma: Banca d'Italia.

Bordignon M., Brusco S. (2010), Una penitenza per chi manda la sanità in rosso, Lavoce.info.

Bordignon M., Turati G. (2008), Health, Fiscal Federalism, and Local Public Services, in Donovan M., Onofri P. (eds.), Italian Politics: Frustrated Aspirations for Change, New York: Berghahn Books.

Bordignon M., Turati G. (2009), Bailing out expectations and public health expenditure, Journal of Health Economics, 28, 305-321.

Caroppo M. S., Turati G. (2007), I sistemi sanitari regionali in Italia. Riflessioni in una prospettiva di lungo periodo, Milano: Vita e Pensiero.

Francese M., Romanelli M. (2010), Health Care in Italy: Expenditure Determinants and Regional Differentials, in A. Testi et al. (eds.), Proceedings of the XXXVI International ORHAS Conference - Operations Research for Patient-Centred Health Care Delivery, Milano: Franco Angeli.

Francese M., Piacenza M., Romanelli M., Turati G. (2010), Understanding inappropriateness in health treatments: The case of caesarean deliveries across Italian regions, Banca d'Italia, Roma, mimeo.

Jourmard I., André C., Nicq C. (2010), Health care systems: Efficiency and institutions, OECD Economics Department Working Papers, No. 769, OECD Publishing, doi: 10.1787/5kmfp5lf5f9t-en.

Lane D. (2009), Into the Hearth of the Mafia. A Journey Through the Italian South, London: Profile Books.

Merlo A., Galasso V., Landi M., Mattozzi A. (2009), The labour market of Italian politicians, PIER Working Paper n. 24, Department of Economics, University of Pennsylvania.

Ministero della Salute (2010), Il sistema di valutazione della performance dei sistemi sanitari regionali, Roma.

Ministero dell'Economia e delle Finanze (2010), Relazione generale sulla situazione economica del Paese, Roma. 
Muraro G. (2011), Federalismo regionale: la rivoluzione può attendere, Lavoce.info.

Oates, W.E. (2005), Toward a second-generation theory of fiscal federalism, International Tax and Public Finance, 12, 349-373.

Pammolli F., Papa G., Salerno N. C. (2009), La spesa sanitaria pubblica in Italia: dentro la "scatola nera" delle differenze regionali, Quaderno Cerm n. 2.

Pelliccia L., Trimaglio F. (2009), I Piani sanitari regionali: aspetti metodologici, contenuto e funzione, in Bosi P., Dirindin N., Turati G. (eds.), Decentramento fiscale, riorganizzazione interna e integrazione socio-sanitaria, Milano: Vita e Pensiero.

Piacenza M., Turati G. (2010), Does Fiscal Discipline towards Sub-national Governments Affect Citizens' Well-being? Evidence on Health, Working Paper n. 56, IEB - Institut d'Economia de Barcelona, Universitat de Barcelona.

Stella G. A., Rizzo S. (2007), La casta, Milano: Rizzoli.

Weingast, B.R. (2009), Second Generation Fiscal Federalism: the implication of fiscal incentives, Journal of Urban Economics, 65, 279-293.

World Health Organization (2000), The World health report 2000: health systems: improving performance, Geneva: WHO. 
DEPARTMENT OF ECONOMICS AND PUBLIC FINANCE "G. PRATO" UNIVERSITY OF TORINO

Corso Unione Sovietica 218 bis - 10134 Torino (ITALY)

Phone: +390116706128 - Fax: +390116706062

Web page: http://eco83.econ.unito.it/prato/ 